\title{
Assessing Naturalness Changes Resulting from a Historical Land Use in Brazil South Region: An Analysis of the 1986-2016 Period
}

\author{
Ivan Luís Rovani ${ }^{1}$, José Eduardo dos Santos¹, Vanderlei Secretti Decian², Elisabete Maria Zanin ${ }^{2}$ \\ ${ }^{1}$ PPG-ERN/UFSCar, Universidade Federal de São Carlos (UFSCar), São Carlos, Brazil \\ ${ }^{2}$ Department of Biological Science, Universidade Regional Integrada do Alto Uruguai e das Missões (URI), Erechim, Brazil \\ Email: ivanrovani@yahoo.com.br, djes@ufscar.br,vdecian@uricer.edu.br,emz@uri.com.br
}

How to cite this paper: Rovani, I.L., dos Santos, J.E., Decian, V.S. and Zanin, E.M. (2019) Assessing Naturalness Changes Resulting from a Historical Land Use in Brazil South Region: An Analysis of the 1986-2016 Period. Journal of Environmental Protection, 10, 149-163.

https://doi.org/10.4236/jep.2019.102010

Received: December 12, 2018

Accepted: January 26, 2019

Published: January 29, 2019

Copyright $\odot 2019$ by author(s) and Scientific Research Publishing Inc. This work is licensed under the Creative Commons Attribution International License (CC BY 4.0).

http://creativecommons.org/licenses/by/4.0/

(c) $\underset{\mathrm{EY}}{\mathrm{C}}$ Open Access

\begin{abstract}
The effects of land use and cover changes and the application of the Urbanity Index were analyzed to identify critical or non-critical naturalness scenery in the Northern Region of Rio Grande do Sul (Brazil), over a period of 30 years. Between 1986 and 2016, the main significant land use change was the reduction of the agricultural anthropic and the increase of the natural vegetation land use areas. About $90 \%-80 \%$ of the total study areas were characterized by anthropic pattern features, with a predominantly agricultural matrix. The conversion of agricultural anthropic into natural areas resulted in increased naturalness landscape and a gain in the stock of natural capital. The increase in the natural vegetation area, mainly to the north and east of the region, set in a steep relief, became remarkable after 1990. The Urbanity Index values evidenced a highest naturalness condition (natural vegetation areas) to the northern and eastern, while a smaller naturalness condition (agricultural and non-agricultural areas) to the southern and western and central of the Northern Region of Rio Grande do Sul. These changes are related to a non-impaired (northern and eastern) and a impaired scenery (southern, western and central portion) of the ecological sustainability of the Northern Region of Rio Grande do Sul, after a 30-year period (1986-2016). These results pointed out that land use transitions resulted in a consolidated farming scenario in which agricultural intensification coincided with the reduction of farming area and increased naturalness as a reverse trend to the agricultural frontier dynamics.
\end{abstract}

\section{Keywords}

Land Use and Cover, Native Vegetation, Urbanity Index,

Environmental Management 


\section{Introduction}

The intensification of changes in land use and cover has been associated with one of the key aspects of socioeconomic development [1] [2] [3], as well as one of the factors responsible for changes in environmental conditions [4] [5].

The conversion of natural vegetation into agricultural anthropogenic uses on a global scale has been pointed out as the main direct factor of pressure on biodiversity and ecosystem services losses, and the emission of greenhouse gases [6] [7], especially when related to the loss of naturalness [8] and forest fragmentation [9]. In this sense, the condition of naturalness for biodiversity and ecosystem services' maintenance are fundamental to ecological sustainability, in order to support the resilience of ecosystems [10] [11].

Environmental changes induced by activities, both locally and globally, in space and time, have led to the use of approaches aimed at the compromise of ecological sustainability [12], focusing on the dependence of human well-being on ecosystem services [13] [14].

Anthropic effects are related in landscapes with the agriculture and ongoing urbanization. A series of changes in landscape and biological characteristics during the conversion of natural to anthropic land use have been described [15]. Naturalness is one of the most important criteria in natural conservation under conditions of environmental changes. A primary prerequisite for the preservation of biodiversity is often assumed to be a high level of naturalness [16]. Although the concept is increasing in importance in some reports, it is almost completely peculiar in others reports [16] [17].

There is a growing demand with existing indicators to assess land use changes related to anthropogenic influences on landscape patterns and processes [18]. These tools also highlight the relationships between the components of natural and anthropogenic landscapes, and how land use changes can influence ecological sustainability, emphasizing the reduction of naturalness due to the replacement of natural components by anthropic ones, monitored in time and space [12] [19] [20] [21]. Among them, the Urbanity Index was used as an indicator of the extent and intensity of the naturalness of heavily altered landscapes, considering the proportion among areas with anthropic interference and natural and semi-natural areas [22] [23] [24].

This work presents an empirical analysis of the effects of land use on the dynamics of composition and naturalness, to identify critical or favorable scenarios for the ecological sustainability of a biocultural landscape of the Northern Region of Rio Grande do Sul (RS), Brazil, based on a descriptive view of the urbanity index, over a 30-year period (1986 to 2016). The impacts of an anthropogenic past resulting from land use transitions, inducing changes in landscape naturalness, have resulted in essential information from the current and historical ecological sustainability scenarios of the Northern Region of Rio Grande do Sul, like a support for decision-making for the management of regional biodiversity. 
Comply with the needs to facilitate the integration of planning and priority in designating areas of outstanding environmental value, or even, what natural vegetation patches areas should be kept in view the maintenance and continuity of ecological processes to ensure ecosystemic services provided to human well-being.

\section{Material and Methods}

\subsection{Study Area}

The Northern Region of Rio Grande do Sul (RS, Brazil) is located between the geographic coordinates $27^{\circ} 12^{\prime} 59^{\prime \prime}$ to $28^{\circ} 00^{\prime} 47^{\prime \prime}$ south latitude, and $51^{\circ} 49^{\prime} 34^{\prime \prime}$ to $52^{\circ} 48^{\prime} 12^{\prime \prime}$ west longitude. It has an extension of 591,610 ha and covers the territorial limits of 31 municipalities: Aratiba, Áurea, Barra do Rio Azul, Barão de Cotegipe, Benjamim Constant do Sul, Campinas do Sul, Carlos Gomes, Centenário, Charrua, Cruzaltense, Entre Rios do Sul, Erebango, Erechim, Erval Grande, Estação, Faxinalzinho, Floriano Peixoto, Gaurama, Getúlio Vargas, Ipiranga do Sul, Itatiba do Sul, Jacutinga, Marcelino Ramos, Mariano Moro, Paulo Bento, Ponte Preta, Quatro Irmãos, São Valentim, Severiano de Almeida, Três Arroios, and Viadutos (Figure 1). It has a total population of 222,926 inhabitants [25].

The territorial limits present a significant diversification in the appropriation of the study area, influencing the interaction between the socioeconomic factors and the biophysical components. The regional economy is based on a highly technified agriculture, mainly with soy, maize and wheat crops, and livestock [26].

The study area includes the Pampa/Prairies and Atlantic Forest Biomes, the latter represented by the Atlantic Forest with Araucarias and Semidecidual Atlantic Forest, considered components of the Subtropical Atlantic Forest. The Atlantic Forest with Araucarias (Mixed Ombrophylous Forest) corresponds to the natural distribution area of Araucaria angustifolia (Bertol.) Kuntze, occupying about $68 \%$ of the study area; while Pampa/Prairies and Semideciduous Atlantic Forest areas occupy, approximately, $17 \%$ and $13 \%$, respectively, of the study area [27].

The climate of the region is characterized as humid subtropical temperate (type Cfa and Cfb of Köppen-Geiger), with annual average temperature of $17 \pm$ $1^{\circ} \mathrm{C}$. The pluviometric regime is regular, with annual average rainfall ranging between 1900 and $2200 \mathrm{~mm}$. The altitude varies from 280 to $900 \mathrm{~m}$, with predominance of flat to wavy relief to the south, and waved to slope to the north of the study area [28]. The Northern Region of Rio Grande do Sul is located in the Serra Geral Formation, with the predominance of Aluminoferric Red Latosol (LVaf) and, by association of Eutrophic Regolithic Neolithic/Eutrophic Haplic/Luvissol Haplic Palic (RRe1-CXe-TXp2) [29].

\subsection{Land Use and Cover}

The land use and cover changes were analyzed based on four LandSat 5 images of the TM sensor (bands 3, 4 and 5), in October 1986, 1991, 2001, 2011, and a 


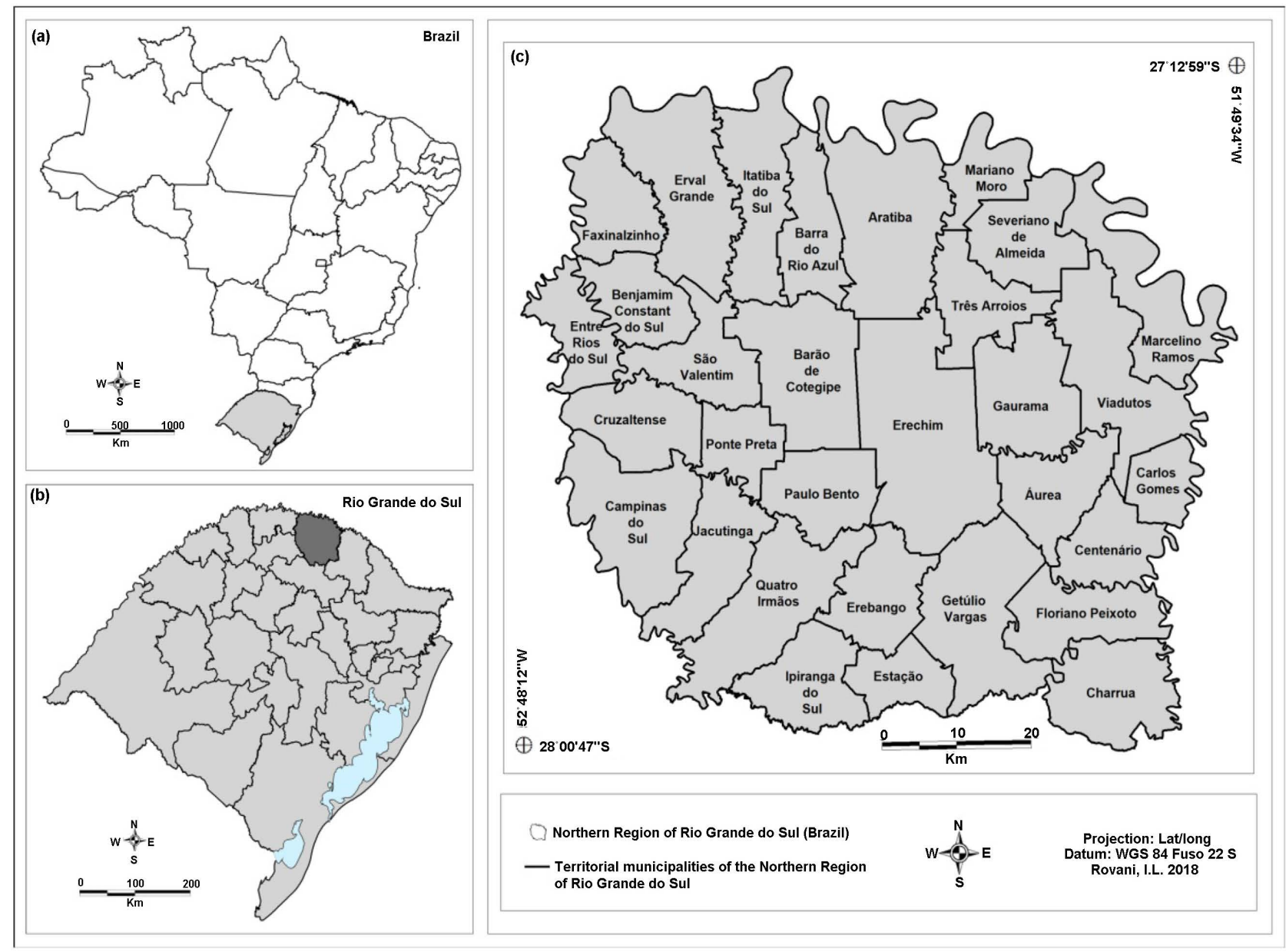

Figure 1. Location and geopolitical limits that cover up the study area: (a) State of Rio Grande do Sul (RS), Brazil; (b) Northern Region of Rio Grande do Sul, RS, Brazil; (c) Territorial limits of the 31 municipalities located in the Northern Region of Rio Grande do Sul (RS, Brazil).

LandSat 8 image of the OLI sensor (bands 4, 5 and 6), September 2016, Orbit-Point 222/079. The georeferencing of the images was performed in the Idrisi Selva 17.0 software [30], using the UTM projection, WGS 84 datum and 22 South spindle, through in situ sampling points.

The mapping and identification of land use and cover types were obtained based on supervised digital classification, using the Idrisi MaxLike (Maximum Likelihood Classification) command. The land use classification was adapted from the Land Use Technical Manual [31].

The sample units of the types of land use and cover of the study area were collected over the 30-year period, to ensure the accuracy and the terrestrial truth patterns. The accuracy was evaluated by the Kappa Coefficient, based on the application of the Errmat module from Idrisi.

The quantitative area values of the land use class were estimated in relation to the extension of the study area, over a 30-year period (1986-2016). The thematic maps of land use and cover, over a 30-year period (1986-2016), were developed in MapInfo Professional 8.5 software. 


\subsection{Naturalness}

The naturalness condition of the Northern Region of Rio Grande do Sul, over a 30-year period (1986-2016) was evaluated by the Urbanity Index (UI) [32] [33]. The UI is often used as an indicator of the extent (Equation (1)) to which landscapes are dominated by heavily human-altered systems:

$$
U I=\log _{10}[(U+A) /(F+W)]
$$

where $U$ : corresponds to urban area; $A$ : agricultural area; $F$ : forest area, and $W$ : aquatic and wetland areas.

The spatial representation of the $U I$ was obtained based on the Raster Vector Area and Image calculator commands in the IDRISI Selva software and fuzzy logic (transformed by a linear function with a minimum value of 0 and a maximum value of 1 ). This representation considers the maximum naturalness condition $(U I=0)$, and the minimum naturalness condition $(U I=1)$, which correspond to the predominance of strongly human-altered systems. Non-impaired scenario to conservation biology and ecological sustainability are related to lower naturalness $\mathrm{UI} \leq 0.3$ values, whereas impaired scenario with high naturalness $\mathrm{UI} \geq 0.7$ values [22].

The naturalness performance was obtained by the transition matrix of the different classes of IB area values, over a 30-year period (1986-2016), using the CrossTab (Cross Tabulation) command from Idrisi. The thematic maps of the naturalness levels related to the UI area values were elaborated using MapInfo Professional.

The land use and cover area values, referring of the $U I$ area values, over a 30-year period, were statistically compared based on a cluster analysis, in a statistical environment $\mathrm{R}$ [34].

\section{Results and Discussion}

\subsection{Land Use and Cover}

The landscape spatial pattern of the Northern Region of Rio Grande do Sul was configured by four (04) land use classes: Natural, Aquatic, Agricultural Anthropic, and Non-Agricultural Anthropic, and their respective areas, over a 30-year period (1986-2016). These classes were later categorized into nine types of land cover: native vegetation, wetlands, water bodies, agriculture, pasture, forestry, bare soil, urbanized area, and road net (Table 1 ).

The landscape composition was described based on land use and cover changes, expressing the performance of anthropic activities in determining the predominant type of land use, over a 30-year period. The agricultural anthropic land use (agriculture, bare soil, pasture, and forestry) showed the highest area values, occupying between $85 \%$ and $70 \%$ of the total study area, over the last 30 years (1986-2016) (Table 1). Through time, a sequence of land use dynamics was observed setting an anthropic matrix, predominantly occupied by farming, with agriculture and soil exposed as the most representative land cover types. 
Table 1. Area values (ha and\%) for the land use and cover types of the Northern Region of Rio Grande do Sul (RS) over a 30-year period (1986-2016).

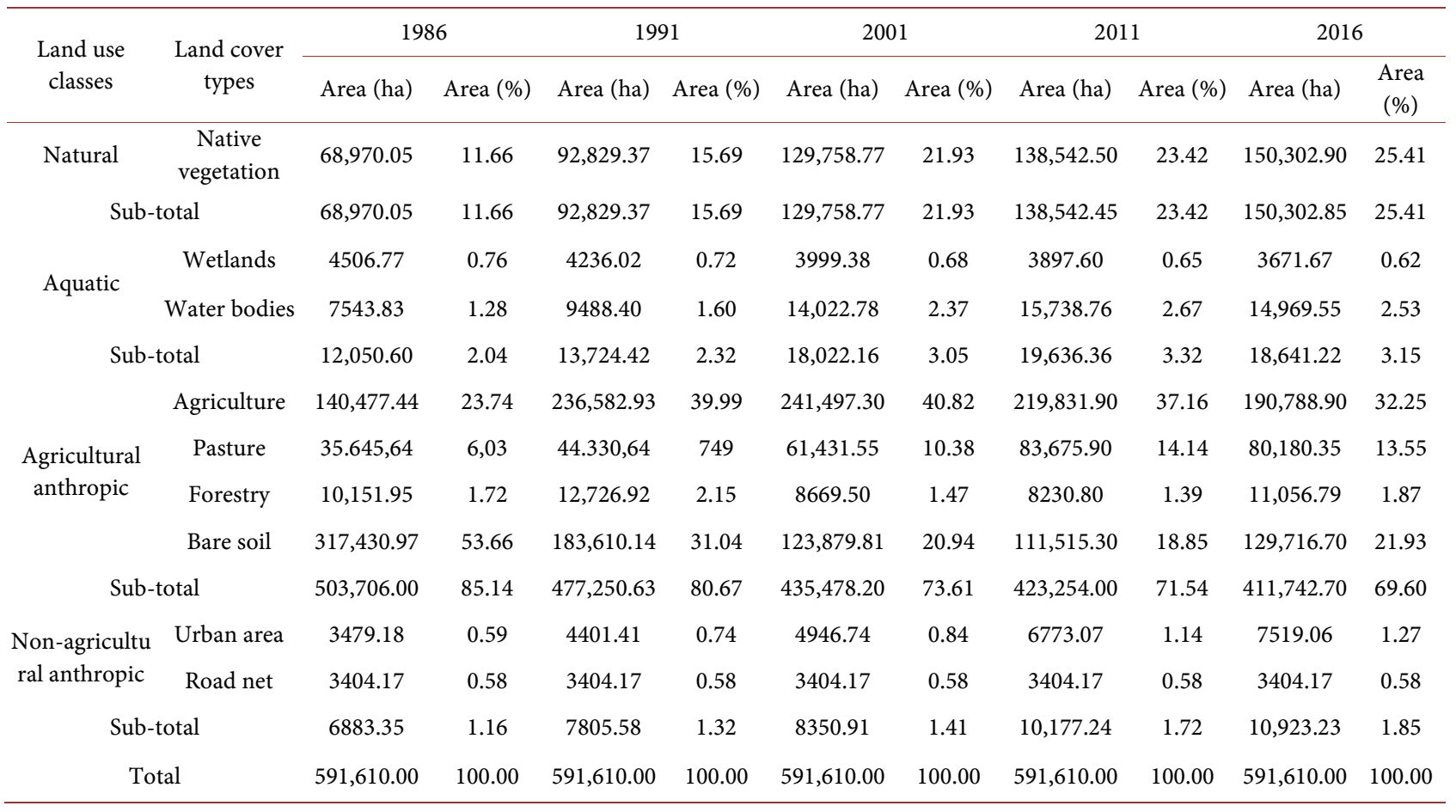

The agricultural anthropic land usehas been initially substituted by a natural one; non-agricultural anthropic land use makes up anthropic matrix as a consequence of ongoing urbanization (Figure 2). The Northern Region of Rio Grande do Sul evidenced an increase of $81,332.85$ ha $(13.75 \%)$ in the native vegetation area, over a 30-year period (1986-2016) (Table 1). This increase became particularly marked in 1990, mainly, in greater slope area to the North and East of the Northern Region of Rio Grande do Sul. The total increase (13.75\%) in the native vegetation area resulted in a quantitative remnant, occupying around $25 \%$, of the Northern Region of Rio Grande do Sul total area (Table 1). This value can be considered below the natural area critical threshold of $30 \%$ to ensure the balance between biodiversity conservation and economic development in a biocultural landscape [24]. This scenery was similar to that observed for other regions of Brazil as previously reported by [22] [23] [35].

The intensification of the farming mechanization in the South of Brazil, since 1980 , with an increase in agricultural productivity per unit area, has been identified as one of the driver of the agricultural reduction area, and the consequent reduction of deforestation and natural vegetation recovery [36] [37] [38] [39] [40].

The replacement of agricultural anthropic areas with subsequent natural vegetation recovery has been described like a feature of regions where socio-economic factors strongly influence land use changes [2] [37] [41]. The increase of forest areas was also previously reported for regions with lower agricultural potential and marked slope gradient [42]. Similar results and reports for 


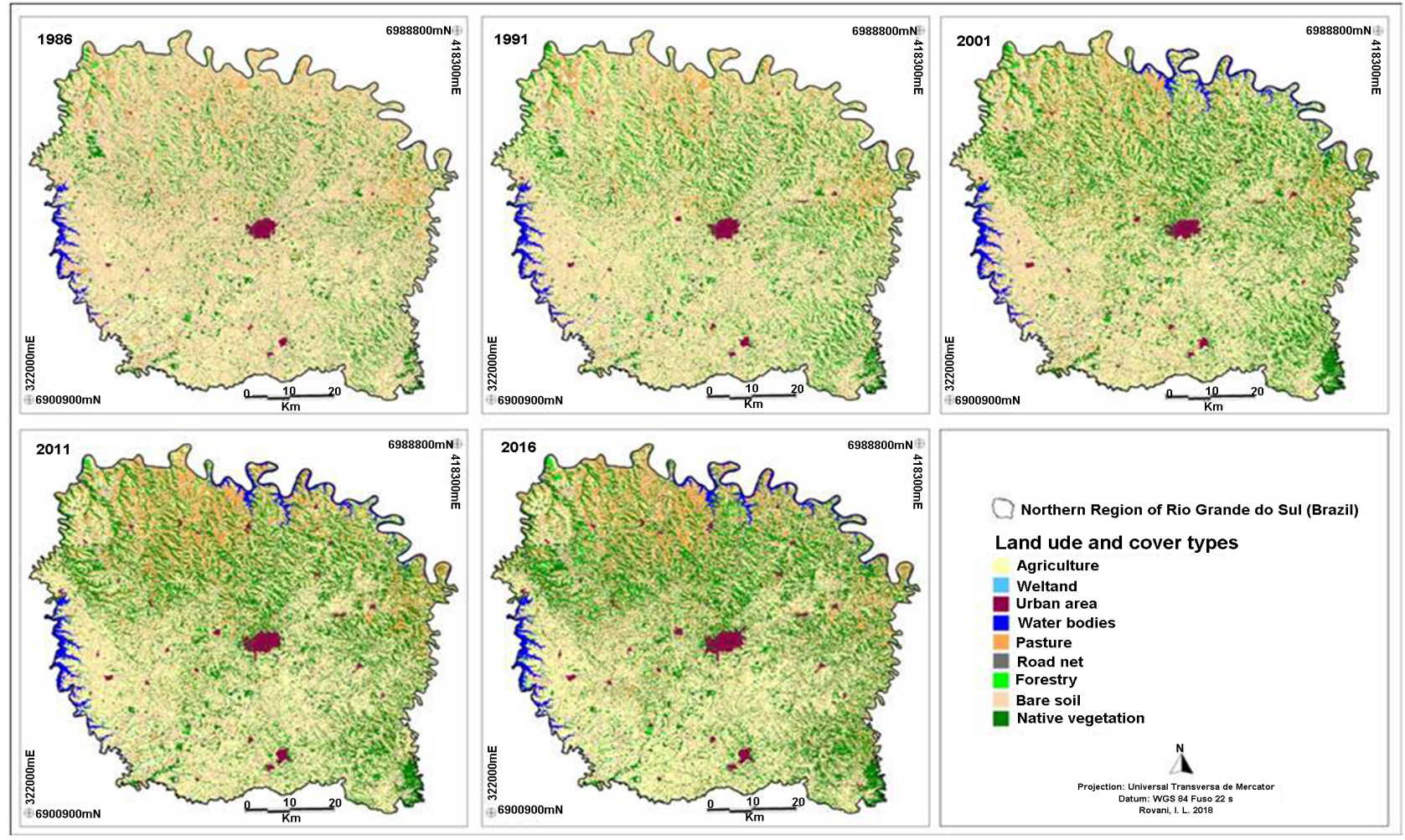

Figure 2. Spatial representation of the land use and cover dynamics of the Northern Region of Rio Grande do Sul (RS) showing the increase of native vegetation in a predominantly anthropic matrix with agriculture, pasture, and exposed soil, over a 30-year period (1986-2016).

the Northern Region of Rio Grande do Sul were previously related by [26] [35] [43] [44].

The increase in pasture areas of 44,534.71 ha (7.52\%), between 1986 and 2016 (Table 1), may be related to the reduction of agricultural areas, mainly in sloping areas, particularly in municipalities with agricultural technology associated with monoculture [43] [44].

The total area of non-agricultural anthropogenic use (urban and road net areas) for the North Region of Rio Grande do Sul increased by 4039.88 ha, over a 30 -year period (Table 1), particularly, as a result of the urbanization expansion, as well as, the exodus of rural population to urban centers. These results are supported by the increase and the reduction of urban and rural populations, respectively, of the Northern Region of Rio Grande do Sul municipalities [25].

There was no change in road net value area (3404.17 ha) in the Northern Region of Rio Grande do Sul between 1986 and 2016 (Table 1). This result is due to the only main roads mapping and rasterization of the study area, due to the resolution of the Landsat images $(30 \mathrm{~m})$ be incompatible with the average width of most of the region's roads (approximately $10 \mathrm{~m}$ ).

The increase in the total area of aquatic environments, equivalent to 7425.72 ha, was mainly supported by the floodplain areas of the Itá and Foz do Chapecó hydroelectric power plants, both on the Uruguay River, and by the Monjolinho Hydroelectric Power Plant, on the Passo Fundo River. Conversely, the reduction 
of the wetlands ( $835.10 \mathrm{ha}$ ) was observed, over a period of 30 years (1986-2016) (Table 1). Wetlands have been intensively modified over time, mainly due to the agricultural expansion in the Rio Grande do Sul province [29].

\subsection{Urbanity Index}

In order to quantify temporal and spatial naturalness dynamics the UI area values of the Northern Region of Rio Grande do Sul were categorized into ten classes (0.0---|0.1 / $0.1--|0.2 / 0.2--| 0.3 / 0.3--0.0$ / 0.4 / $0.4---0.5 / 0.5--\mid 0.6 /$ $0.6---|0.7 / 0.7---| 0.8 / 0.8---|0.9 / 0.9---| 1.0)$, and later at four levels of: 1 ) high naturalness (natural areas with or without minimal anthropogenic interference); 2) medium/high naturalness (natural areas with anthropic influence); 3) medium/low naturalness (anthropogenic areas intentionally established by human activities with reduced self-regulation capacity); 4) low naturalness (predominance of non-agricultural anthropogenic areas with reduced self-regulation capacity). The area values (ha/\%) occupied for each naturalness level, and the temporal and spatial naturalness dynamics of the Northern Region of Rio Grande do Sul, over a 30-year period (1986-2016), are represented in Table 2 and Figure 3, respectively.

Three naturalness performances of the Northern Region of Rio Grande do Sul, over a 30-year period, were identified: 1) increased naturalness (areas of high and medium/high naturalness) resulting, respectively, from the increase of natural areas with or without minimal anthropic influence, and of natural areas with anthropic influence, equivalent to changes from $0.94 \%$ to $2.63 \%$, and from $13.33 \%$ to $26.29 \%$, of the total study area (Table 2). Areas of high naturalness are associated with patches of natural vegetation, in the North and East of the Northern Region of Rio Grande do Sul, particularly, through two remnants of natural vegetation, with areas greater than 1000 ha, located in Indigenous Land, respectively, to the northwest and southeast of the Northern Region of Rio Grande do Sul (Figure 3, 2016); 2) reduction of naturalness (areas of low naturalness), specifically, related to the ongoing urbanization process, equivalent to a change from $0.38 \%$ to $0.57 \%$ of the total study area; Reduction of the farming matrix, from $85.35 \%$ to $70.51 \%$ of the total study area, mainly due to the replacement of agricultural with natural vegetation areas (Table 2).

Even considering the trend towards improvement in the naturalness performance, particularly, for the period 2001-2016, the Northern Region of Rio Grande do Sul continues under the influence of pressure factors related to the continuity of agricultural and non-agricultural anthropic land uses. This trend is supported by the predominance of areas with medium/low and low naturalness, categorized by UI values between $>0.5$ to 1.0 (Table 2). The predominance of agricultural anthropic areas reverting to landscapes with low naturalness is also reported in other studies [23] [45] [46].

\subsection{Ecological Sustainability}

A cluster analysis between the land use area values, together with a naturalness 
Table 2. Temporal quantification of naturalness levels based on the area values (ha and\%) for the different classes of the Urbanity Index (UI) of the Northern Region of Rio Grande do Sul, over a 30-year period (1986-2016). The area values (\%) of each naturalness level in the period of 1986-2016 are highlighted.

\begin{tabular}{|c|c|c|c|c|c|c|c|c|c|c|c|c|}
\hline \multirow[b]{2}{*}{$\begin{array}{c}\text { Urbanity } \\
\text { index } \\
\text { class }\end{array}$} & \multirow[b]{2}{*}{$\begin{array}{c}\text { Naturalness } \\
\text { level }\end{array}$} & \multicolumn{2}{|c|}{1986} & \multicolumn{2}{|c|}{1991} & \multicolumn{2}{|c|}{2001} & \multicolumn{2}{|c|}{2011} & \multicolumn{2}{|c|}{2016} & \multirow[b]{2}{*}{$\begin{array}{c}\text { Total study area } \\
(\%) \\
1986 \\
016\end{array}$} \\
\hline & & $\begin{array}{c}\text { Area } \\
\text { (ha) }\end{array}$ & $\begin{array}{l}\text { Area } \\
(\%)\end{array}$ & Area (ha) & $\begin{array}{c}\text { Area } \\
(\%)\end{array}$ & $\begin{array}{l}\text { Area } \\
\text { (ha) }\end{array}$ & $\begin{array}{l}\text { Area } \\
(\%)\end{array}$ & $\begin{array}{c}\text { Area } \\
\text { (ha) }\end{array}$ & $\begin{array}{l}\text { Area } \\
(\%)\end{array}$ & $\begin{array}{c}\text { Area } \\
\text { (ha) }\end{array}$ & $\begin{array}{l}\text { Area } \\
(\%)\end{array}$ & \\
\hline $0.0---\mid 0.1$ & \multirow{2}{*}{ High } & 5.18479 & 0.88 & 7.13974 & 1.21 & 14.62513 & 2.47 & 15.01566 & 2.54 & 15.54889 & 2.63 & \multirow{2}{*}{$\begin{array}{l}0.94 \\
2.63\end{array}$} \\
\hline $0.1---\mid 0.2$ & & 362.76 & 0.06 & 721.55 & 0.12 & 940.487 & 0.16 & 968.64 & 0.16 & 0.00 & 0.00 & \\
\hline $0.2---\mid 0.3$ & \multirow{3}{*}{$\begin{array}{l}\text { Medium/ } \\
\text { high }\end{array}$} & 2.88025 & 0.49 & 3.26772 & 0.55 & 1.71113 & 0.29 & 8.11644 & 1.37 & $3.101,19$ & 0.52 & \multirow{3}{*}{$\begin{array}{l}13.33 \\
26.29\end{array}$} \\
\hline $0.3---\mid 0.4$ & & 4.15142 & 0.70 & 11.10433 & 1.88 & 10.08166 & 1.70 & 17.40777 & 2.94 & 14.50599 & 2.45 & \\
\hline $0.4---\mid 0.5$ & & 71.79563 & 12.14 & 87.23971 & 14.75 & 122.94576 & 20.78 & 118.92582 & 20.10 & 137.96074 & 23.32 & \\
\hline 0.5---|0.6 & \multirow{3}{*}{ Medium/low } & 388.39793 & 65.64 & 369.95597 & 62.53 & 325.57925 & 55.03 & 254.28803 & 42.98 & 299.10757 & 50.56 & \multirow{3}{*}{$\begin{array}{l}85.35 \\
70.51\end{array}$} \\
\hline $0.6---\mid 0.7$ & & 107.48992 & 18.17 & 101.73020 & 17.20 & 103.49513 & 17.49 & 131.22960 & 22.18 & 111.68046 & 18.88 & \\
\hline $0.7---\mid 0.8$ & & 9.09410 & 1.54 & 8.05887 & 1.36 & 9.84101 & 1.66 & 39.36550 & 6.65 & 6.32478 & 1.07 & \\
\hline $0.8---\mid 0.9$ & \multirow{2}{*}{ Low } & 0.00 & 0.00 & 0.00 & 0.00 & 0.00 & 0.00 & 3.25965 & 0.55 & 0.00 & 0.00 & \multirow{2}{*}{$\begin{array}{l}0.38 \\
0.57\end{array}$} \\
\hline 0.9----|0 & & 2.25320 & 0.38 & 2.39191 & 0.40 & 2.39044 & 0.40 & 3.03289 & 0.51 & 3.38038 & 0.57 & \\
\hline & Total & $591,610.00$ & 100,00 & $591,610.00$ & 100,00 & $591,610.00$ & 100.00 & $591,610.00$ & 100.00 & $591,610.00$ & 100.00 & $100.00 \quad 100.00$ \\
\hline
\end{tabular}

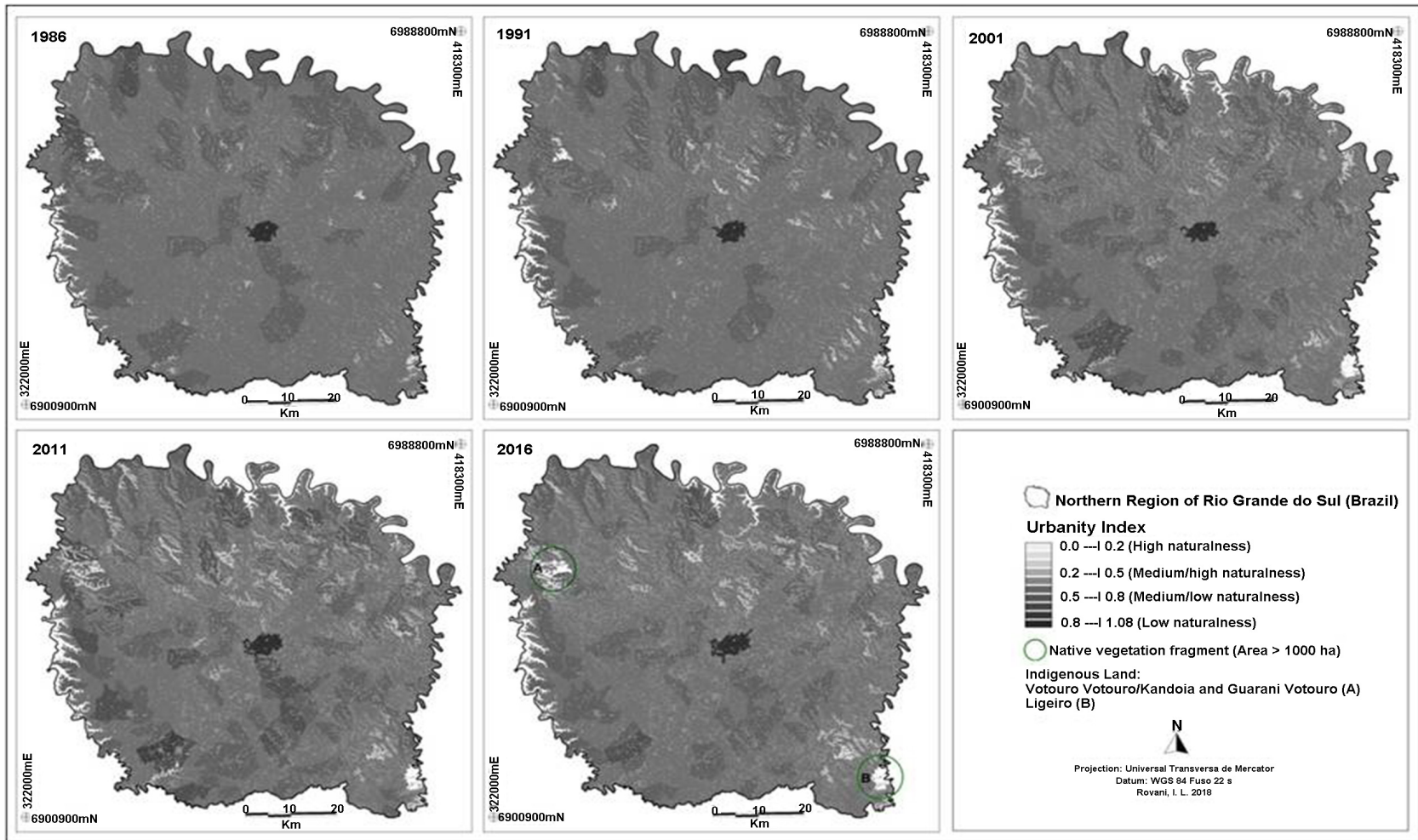

Figure 3. Temporal and spatial representation of naturalness levels, based on the Urbanity Index classes of area values, from the Northern Region of Rio Grande do Sul (RS, Brazil), over a 30-year period (1986-2016), evidencing the increase of areas with high (natural vegetation) and low naturalness (urban areas). Areas of high naturalness stand out at the north and east of the study area. Two remaining fragments of natural vegetation, with areas greater than 1000 ha, located in the Votouro, Votouro/Kandoia and Guarani Votouro (A) and Ligeiro (B) Indigenous Land, respectively, located to the northwest and southeast of the study (Figure 3, 2016) was highlighted. 
levels, and the time period (1986, 1991, 2001, 2011, and 2016), identified two scenery of ecological sustainability for the Northern Region of Rio Grande do Sul, over a 30-year period. One with a impaired ecological sustainability related to agricultural anthropic area values, related to higher naturalness UI values (0.5---|0.8 and 0.8---|1.0), particularly, for 1986 and 1991; and another with a non-impaired ecological sustainability reveled by the increase of natural and aquatic areas, associated to lower naturalness UI values (0.0--- $\mid 0.2$ e $0.2---\mid 0.5)$, for 2001, 2011 and 2016 (Figure 4). The grouping related to the first scenario (1986 and 1991) is due to the reduction of the agricultural anthropic areas in relation to the other years, while the second scenario $(2001,2011$, and 2016) is related to the increase of natural vegetation and aquatic areas compared to previous periods.

Compromising conditions represented by UI values $(0.8---\mid 1.0)$ were related to the anthropic (agricultural and urban) areas, while non-compromising conditions to ecological sustainability represented by UI values $(0.0---\mid 0.2)$ were related to aquatic and natural areas (Table 2), mainly due to the largest patches of native vegetation in the region (Figure 3 ). That scenery supports the relevance of wetlands, water bodies and native vegetation to maintain the naturalness and ecological sustainability of the study area. The transition from agricultural anthropic to natural land use resulted in a gain in the stock of natural capital and an increase in naturalness, promoting the improvement of the ecological sustainability of the Northern Region of Rio Grande do Sul, over a 30-year period (1986-2016).

\section{Conclusions}

Over a 30-year period (1986-2016), a process of land appropriation was observed, with anthropic agricultural land use constituting the main responsibility of causing changes in the landscape composition of the Northern Region of Rio Grande do Sul. The landscape spatial composition resulting from the conversion and substitution of one land use type by another configured an increase in the stock of natural vegetation immersed in a predominantly anthropic matrix, with agriculture and bare soil as the most representative land cover types. The natural vegetation increase became noticeable from 1990, mainly in areas located to the north and east of the study area, set out in more steep relief.

The land use and cover transitions emphasized that farming intensification reduced the agricultural production area, with approximately $90 \%$ to $80 \%$ of the total area of the North Region of Rio Grande do Sul, remaining unchanged in relation to the different types of land use and cover, over a 30 -year period (1986-2016).

The conversion of anthropic agricultural into natural areas resulted in three naturalness performances of the Northern Region of Rio Grande do Sul, over a 30-year period: 1) increase in naturalness level (high and medium/high naturalness areas) resulting from the increase of natural areas, with or without a minimal anthropic influence, and natural areas with anthropic influences, respectively; 


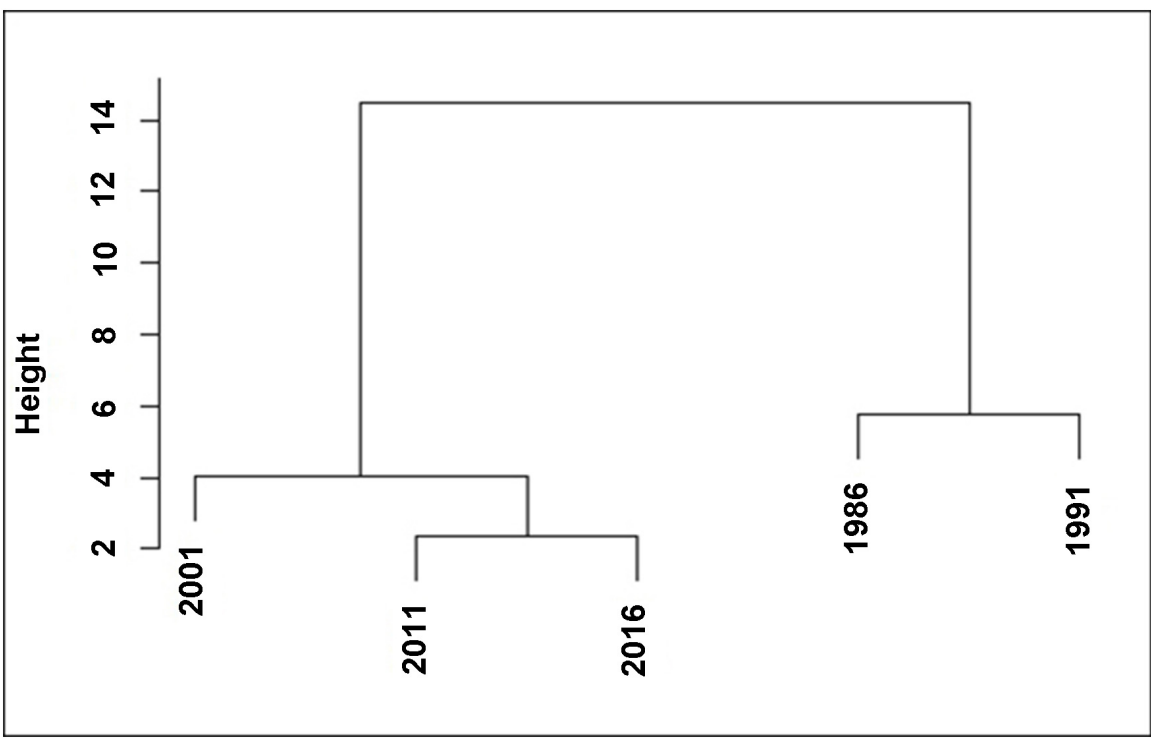

Figure 4. Cluster analysis between the land use area values, associated with a naturalness conditions, and the years 1986, 1991, 2001, 2011, and 2016, showing scenarios of high and low ecological sustainability for 2001-2011-2016 and 1986-1991 aggregate, respectively, for the Northern Region of Rio Grande do Sul, over a 30-year period.

2) decrease of the naturalness level (low naturalness area), specifically related to the urbanization process; 3 ) reduction in the area of the agricultural anthropic matrix supporting the substitution of the farming to natural vegetation areas.

The values of land use areas associated with UI values, over a 30-year period $(1986,1991,2001,2011$, and 2016) identified a scenery with impaired ecological sustainability related to lower naturalness level due to the high area values of anthropic agricultural land use, particularly, for 1986 and 1991; and another one of a non-impaired ecological sustainability related to a higher naturalness level due to the increase of the natural and aquatic land use areas, for 2001, 2011 and 2016.

The impacts of an anthropogenic past result from changes in land use, induce changes in landscape naturalness, and provide essential information for the current and historical ecological sustainability scenery of the Northern Region of Rio Grande do Sul, as a support for decision-making for the management of regional biodiversity. It's also make it possible for policy makers, scientists and stakeholders to identify at a glance the land uses which are hindered or enhanced under various scenarios of land use change, over the 30-year period. Overlaying UI values and municipalities limits enable us to provide essential information about current and historical land use, and the monitoring of naturalness dynamics of each territorial municipality, in time and space, identifying which of them the amount of natural area is below of a critical threshold.

\section{Conflicts of Interest}

The authors declare no conflicts of interest regarding the publication of this paper. 


\section{References}

[1] Liu, Y. (2018) Introduction to Land Use and Rural Sustainability in China. Land Use Policy, 74, 1-4. https://doi.org/10.1016/j.landusepol.2018.01.032

[2] Melendez-Pastor, I., Hernández, E.I., Navarro-Pedreño, J. and Gómez, I. (2014) Socioeconomic Factors Influencing Land Cover Changes in Rural Areas: The Case of the Sierra de Albarracín (Spain). Applied Geography, 52, 34-45.

https://doi.org/10.1016/j.apgeog.2014.04.013

[3] Parcerisas, L., Marullb, J., Pino, J., Tello, E., Coll, F. and Basnou, C. (2012) Land Use Changes, Landscape Ecology and Their Socioeconomic Driving Forces in the Spanish Mediterranean Coast (El Maresme County, 1850-2005). Environmental Science \& Policy, 23, 120-132. https://doi.org/10.1016/j.envsci.2012.08.002

[4] Ellis, E.C. (2015) Ecology in an Anthropogenic Biosphere. Ecological Monographs, 85, 287-331. https://doi.org/10.1890/14-2274.1

[5] Kleemann, J., Baysal, G., Bulley, H.N.N. and Fürst, C. (2017) Assessing Driving Forces of Land Use and Land Cover Change by a Mixed-Method Approach in North-Eastern Ghana, West Africa. Journal of Environmental Management, 196, 411-442. https://doi.org/10.1016/j.jenvman.2017.01.053

[6] Foley, J.A., Defries, R., Asner, G.P., Barford, C., Bonan, G., Carpenter, S.R., Stuart Chapin, F., Coe, M.T., Daily, G.C., Gibbs, H.K., Helkowski, J.H., Holloway, T., Howard, E.A., Kucharik, C.J., Monfreda, C., Patz, J.A., Colin Prentice, I., Ramankutty, N. and Snyder, P.K. (2005) Global Consequences of Land Use. Science, 309, 570-574. https://doi.org/10.1126/science.1111772

[7] Hörtenhuber, S., Piringer, G., Zollitsch, W., Lindenthal, T. and Winiwarter, W. (2014) Land Use and Land Use Change in Agricultural Life Cycle Assessments and Carbon Footprints-The Case for Regionally Specific Land Use Change versus Other Methods. Journal of Cleaner Production, 73, 31-39. https://doi.org/10.1016/j.jclepro.2013.12.027

[8] Jansen, F., Zerbe, S. and Succow, M. (2009) Changes in Landscape Naturalness Derived from a Historical Land Use Register-A Case Study from NE Germany. Landscape Ecology, 24, 185. https://doi.org/10.1007/s10980-008-9297-5

[9] Davis, A.J.S., Thill, J.C. and Meentemeyer, R.K. (2017) Multi-Temporal Trajectories of Landscape Change Explain Forest Biodiversity in Urbanizing Ecosystems. Landscape Ecology, 32, 1789-1803. https://doi.org/10.1007/s10980-017-0541-8

[10] Folke, C., Carpenter, S., Walker, B., Scheffer, M., Elmqvist, T., Gunderson, L. and Holling, C.S. (2004) Regime Shifts, Resilience, and Biodiversity in Ecosystem Management. Annual Review of Ecology, Evolution, and Systematics, 35, 557-581. https://doi.org/10.1146/annurev.ecolsys.35.021103.105711

[11] Hooper, D.U., Chapin, F.S., Ewel, J.J., Hector, A., Inchausti, P., Lavorel, S., Lawton, J.H., Lodge, D.M., Loreau, M., Naeem, S., Schmid, B., Seta, H., Symstad, J., Vandermeer, J. and Wardle, D.A. (2005) Effects of Biodiversity on Ecosystem Functioning: A Consensus of Current Knowledge. Ecological Monographs, 75, 3-35. https://doi.org/10.1890/04-0922

[12] Turner II, B.L., Kasperson, R.E., Matson, P.A., Mccarthy, J.J., Corell, R.W., Christensen, L., Eckley, N., Kasperson, J.X., Luers, A., Martello, M.L., Polsky, C., Pulsipher, A. and Schiller, A. (2003) A Framework for Vulnerability Analysis in Sustainability. Proceedings of the National Academy of Sciences of the United States of America, 100, 8074-8079. https://doi.org/10.1073/pnas.1231335100

[13] De Groot, R.S., Blignaut, J., Van Der Ploeg, S., Aronson, J., Elmqvist, T. and Farley, J. (2013) Benefits of Investing in Ecosystem Restoration. Conservation Biology, 27, 
1286-1293. https://doi.org/10.1111/cobi.12158

[14] Wu, J. (2013) Landscape Sustainability Science: Ecosystem Services and Human Well-Being in Changing Landscapes. Landscape Ecology, 28, 999-1023. https://doi.org/10.1007/s10980-013-9894-9

[15] Bogaert, J., Vranken, I. and André, M. (2014) Anthropogenic Effects in Landscapes: Historical Context and Spatial Pattern. Biocultural Landscapes, 89-112. https://doi.org/10.1007/978-94-017-8941-7_8

[16] Winter, S. (2012) Forest Naturalness Assessment as a Component of Biodiversity Monitoring and Conservation Management. Forestry: An International Journal of Forest Research, 85, 293-304. https://doi.org/10.1093/forestry/cps004

[17] McRoberts, R., Winter, S., Chirici, G. and LaPoint, E. (2012) Assessing Forest Naturalness. Forestry Science, 58, 294-309. https://doi.org/10.5849/forsci.10-075

[18] Rudisser, J., Tasser, E. and Tappeiner, U. (2012) Distance to Nature. A New Biodiversity Relevant Environmental Indicator Set at the Landscape Level. Ecological Indicators, 15, 208-216. https://doi.org/10.1016/j.ecolind.2011.09.027

[19] Wiens, J.A., Stenseth, N.C., Horne, B. and Van, R.A. (1993) Ecological Mechanisms and Landscape Ecology. Oikos, 66, 369-380. https://doi.org/10.2307/3544931

[20] Haberl, H., Wackernagel, M. and Wrbka, T. (2004) Land Use and Sustainability Indicators. An Introduction. Land Use Policy, 21, 193-198. https://doi.org/10.1016/j.landusepol.2003.10.004

[21] Fushita, A.T., Santos, J.E., Rocha, Y.R. and Zanin, E.M. (2017) Historical Land Use/Cover Changes and the Hemeroby Levels of a Bio-Cultural Landscape: Past, Present and Future. Journal of Geographic Information System, 9, 576-590. https://doi.org/10.4236/jgis.2017.95036

[22] Fushita, A.T., Santos, J.E., De Souza, I.M.M., Romanini, E. and Costa, R.T. (2016) Landscape Structural Indicators as a Tool to Assess Land Use Changes in Planning for Sub-Basin Sustainability (Southeastern Brazil). Journal of Water Resource and Protection, 8, 482-492. https://doi.org/10.4236/jwarp.2016.84041

[23] Romanini, E., Fushita, A.T. and Santos, J.E. (2016) An Approach to Environmental Planning and Sustainable Management of Watersheds and Municipalities in Southeastern Brazil. Open Journal of Ecology, 6, 667-685.

https://doi.org/10.4236/oje.2016.611062

[24] Santos, J.E., Fushita, A.T., De Souza, I.M.M., Amorim, L.A. and Andrade, V.A.D. (2015) Agriculture and Forest Transition: Understanding of Land Use Change in a Cultural Landscape. Open Journal of Applied Sciences, 5, 797-807. https://doi.org/10.4236/ojapps.2015.512076

[25] IBGE (2017) Instituto Brasileiro de Geografia e Estatística. População estimada 2017. IBGE, Rio de Janeiro.

[26] Decian, V.S., Zanin, E.M., Henke-Oliveira, C., Rosset-Quadros, F. and Ferrari, C. (2009) Uso e ocupação da terra na região Alto Uruguai do Rio Grande do Sul e obtenção de banco de dados relacional de fragmentos de vegetação arbórea. Perspectiva, 33, 165-176.

[27] Oliveira-Filho, A., Budke, J.C., Jarenkow, J.A., Eisenlohr, P.V. and Neves, D.R.M. (2015) Delving into the Variations in Tree Species Composition and Richness across South American Subtropical Atlantic and Pampean Forests. Journal of Plant Ecology, 8, 242-260. https://doi.org/10.1093/jpe/rtt058

[28] Alvares, C.A., Stape, J.L., Sentelhas, P.C., Gonçalves, J.L.M. and Sparovek, G. (2013) Koppen's Climate Classification Map for Brazil. Meteorologische Zeitschrift, 22, 
711-728. https://doi.org/10.1127/0941-2948/2013/0507

[29] Streck, E.V., Kämpf, N., Dalmolin, R.S.D., Klamt, E., Nascimento, P.C., Schneider, P., Giasson, E. and Pinto, L.F.S. (2008) Solos do Rio Grande do Sul. Emater/RS, Porto Alegre.

[30] Eastman, J.R. (2012) IDRISI Selva Manual. Clark Labs, Clark University, Worcester, $322 \mathrm{p}$.

[31] IBGE (2013) Instituto Brasileiro de Geografia e Estatística. Manual técnico de uso da terra. IBGE, Rio de Janeiro.

[32] O’Neill, R.V., Milne, B.T., Turner, M.G. and Gardner, R.H. (1988) Resource Utilization Scales and Landscape Pattern. Landscape Ecology, 2, 63-69. https://doi.org/10.1007/BF00138908

[33] Wrbka, T., Erb, K.H., Schulz, N.B., Peterseila, J., Hahna, C. and Haberl, H. (2004) Linking Pattern and Process in Cultural Landscapes. An Empirical Study Based on Spatially Explicit Indicators. Land Use Policy, 21, 289-306. https://doi.org/10.1016/j.landusepol.2003.10.012

[34] R Core Team (2017) R: A Language and Environment for Statistical Computing. R Foundation for Statistical Computing, Vienna. https://www.R-project.org/

[35] Scariot, E.C., Almeida, D. and Santos, J.E. (2015) Connectivity Dynamics of Araucaria Forest and Grassland Surrounding Passo Fundo National Forest, Southern Brazil. Natureza \& Conservação, 13, 54-59. https://doi.org/10.1016/j.ncon.2015.05.001

[36] Ronquim, C.C. and Fonseca, M.F. (2018) Avanço das áreas de cana-de-açúcar e alterações em áreas de agropecuária no interior paulista. Embrapa Territorial, Campinas, $48 \mathrm{p}$.

[37] Barretto, A.G.O.P., Berndes, G., Sparovek, G. and Wirsenius, S. (2013) Agricultural Intensification in Brazil and Its Effects on Land-Use Patterns: An Analysis of the 1975-2006 Period. Global Change Biology, 19, 1804-1815. https://doi.org/10.1111/gcb.12174

[38] Benetti, M.D. (2010) O agronegócio gaúcho entre os anos 1980 e 2008. In: Conceição, O.A.C., Grando, M.Z., Teruchkin, S.U. and Faria, L.A.E., Eds., Três décadas de economia gaúcha: O movimento da produção, FEE, Porto Alegre, 1-34.

[39] Grau, H.R., Aide, T.M., Zimmerman, J.K., Thomlinson, J.R., Helmer, E. and Zou, X. (2003) The Ecological Consequences of Socioeconomic and Land Use Change in Post Agriculture Puerto Rico. Bioscience, 12, 1159-1168. https://doi.org/10.1641/0006-3568(2003)053[1159:TECOSA]2.0.CO;2

[40] Parsons, A.J. (2014) Abandonment of Agricultural Land, Agricultural Policy and Land Degradation in Mediterranean Europe. In: Mueller, E.N., Wainwright, J., Parsons, A.J. and Turnbull, L., Eds., Patterns of Land Degradation in Drylands, Springer, Berlin, 357-366. https://doi.org/10.1007/978-94-007-5727-1_14

[41] Piran, N. (2001) Agricultura familiar: Lutas e perspectivas no Alto Uruguai. Erechim-EdiFAPES, Série Pensamento Acadêmico.

[42] Nainggolan, D., De Vente, J., Boix-Fayos, C., Termansen, M., Hubacek, K. and Reed, M.S. (2012) Afforestation, Agricultural Abandonment and Intensification: Competing Trajectories in Semi-Arid Mediterranean Agro-Ecosystems. Agriculture, Ecosystems \& Environment, 159, 90-104. https://doi.org/10.1016/j.agee.2012.06.023

[43] Rovani, I.L., Santos, J.E., Zanin, M.E., Hepp, L.U. and Decian, V.S. (2016) Land Use Changes in a Southern Brazil Landscape. In: II Simpósio Internacional de Ecologia: Ecologia no Antropoceno, Universidade Federal de São Carlos, São Paulo, 172-176. 
[44] Rovani, I.L., Brandalise, M., Prandel, J.A., Backes, J.C., Quadros, F.R., Zanin, E.M., Decian, V.S. and Santos, J.E. (2017) Uso e cobertura da terra e declividade na Região Norte do Rio Grande do Sul. In: XXVI Semana Alto Uruguai do Meio Ambiente (SAUMA) I Encontro Internacional de Ecologia e Conservação II Workshop sobre Gestão e Conservação Ambiental do PPG Ecologia, EdiFAPES, Erechim, 193-201.

[45] Fushita, A.T., Santos, J.E., Souza, I.M.M., Costa, R.T., Romanini, E., Andrade, V.A.D. and Amorim, L.M. (2016b) Detection in Land Cover Change Trajectories Using Remote Sensing. A Case Study of Southeast Brazil Region. International Journal of Applied Science and Technology, 6, 58-66.

[46] Almeida, D., André, M., Scariot, E.C., Fushita, A.T., Santos, J.E. and Bogaert, J. (2018) Temporal Change of Distance to Nature Index for Anthropogenic Influence Monitoring in a Protected Area and Its Buffer Zone. Ecological Indicators, 91, 189-194. https://doi.org/10.1016/j.ecolind.2018.03.055 